\title{
SUPERPLASTIC FORMING OF INCONEL ALLOY 718SPF
}

\author{
Gaylord D. Smith and H. Lee Flower \\ Inco Alloys International, Inc. \\ P. O. Box 1958 \\ Huntington, WV 25720
}

\begin{abstract}
Superplastic forming (SPF) has become an important manufacturing method for aerospace and fuselage components. The basic reasons for the popularity of this process are reviewed and the compatibility of fine-grained INCONEL ${ }^{\circledR}$ alloy 718 SPF ${ }^{(i x)}$ to superplastic forming are presented in this paper.

The temperature limitations of current aluminum and titanium alloys employed in SPF parts for gas turbine components have prompted the need to find a high temperature nickel-base alloy amenable to current SPF practice and equipment. An optimum temperature, the anticipated flow stresses and preferred strain rates are proposed for INCONEL alloy 718SPF and found to be completely compatible with current SPF equipment now in use by the aerospace industry and their fabricators.

The wide use of INCONEL alloy 718 SPF (UNS NO7718) in aerospace applications is based on its high temperature strength and excellent fatigue resistance. These properties must be maintained in any SPF-processed component. Demonstration that these properties are maintained and even exceeded is established using data obtained from a prototype part for a candidate noise suppressor assembly.

Finally the influence of INCONEL alloy 718SPF and the SPF method of processing on the design and manufacture of future gas turbine engines is considered and the advantages assessed from the aerospace manufacturers' viewpoint.

${ }^{\circledR}$ INCONEL and $718 \mathrm{SPF}$ are trademarks of the Inco family of companies.

\footnotetext{
Superalloys 718, 625, 706 and Various Derivatives

Edited by E.A. Loria

The Minerals, Metals \& Materials Society, 1994
} 


\section{Introduction}

There is a market need for complex shaped parts for commercial and military aircraft applications requiring high nickel alloys to withstand a combination of high temperature, hot gas corrosion and high strength. Conventional methods of fabricating these components requires extensive welding and fabrication methods resulting in higher than desired costs and excessive parts inventories. Superplastic forming, now highly sophisticated and used extensively for producing titanium and aluminum alloy aircraft parts, would be an ideal solution for producing nickel alloy components as well. However, for this to occur, a minimum level of technology must exist for an alloy which both meets the technical requirements of the end-use and is amenable to the SPF practices and equipment now in commercial use. This paper seeks to show the applicability of INCONEL alloy 718SPF to this manufacturing method by describing the SPF characteristics of this alloy and the subsequent properties and microstructure of the finished part. The merits of INCONEL alloy 718 for commercial and military aircraft airframe and engine components have been long established and are widely known.

\section{Commercial Significance Of INCONEL Alloy 718SPF}

Combining SPF capabilities with the properties of INCONEL alloy 718SPF opens up major opportunities for engine design improvements and production economics. This combination will help gas turbine engine manufacturers create designs that are not currently feasible. Superplastic forming has the unique capability to allow the manufacture of large, complex and detailed parts, thus combining many small parts. This increases part integrity by minimizing joining and joining problems, and rcduces tooling costs and inventory complexities. Most importantly, superplastic forming of INCONEL alloy 718SPF allows designers to fabricate components, now made with aluminum or titanium alloys, that meet higher strength, fatigue and temperature requirements.

\section{INCONEL Alloy 718SPF Characteristics}

The nominal composition of INCONEL alloy 718SPF is listed in Table I. While chemistry modification is not necessary to produce the fine microstructure needed for SPF, the maximum carbon and niobium contents have been lowered modestly to minimize carbide precipitation during part manufacture. Maintaining the composition within existing AMS specifications permits direct use of the material without extensive qualification testing. The fine-grained condition (ASTM grain size\#10 or finer) is achieved through alteration of conventional cold rolling and annealing practices. This modified process limits commercially available sheet thickness to $3.2 \mathrm{~mm}$ (0.08 in) or thinner. The new product meets the AMS 5596G annealed-plus-aged properties and exceeds the room temperature tensile property maxima as-annealed. Table II compares the tensile and stress rupture properties of INCONEL alloy 718SPF with AMS 5596G 
requirements. The fine-grain microstructure of the alloy has been found to dramatically boost fatigue resistance as compared to conventionally produced INCONEL alloy 718 which, nominally, is ASTM grain size \#4-6. Table III compares the tension-tension fatigue resistance of INCONEL alloy 718 SPF with conventionally produced INCONEL alloy 718 at $316^{\circ} \mathrm{C}\left(600^{\circ} \mathrm{F}\right)$ and $538^{\circ} \mathrm{C}\left(1000^{\circ} \mathrm{F}\right)$.

\section{SPF Characteristics of INCONEL alloy 718 SPF}

$954^{\circ} \mathrm{C}\left(1,750^{\circ} \mathrm{F}\right)$ was chosen as the aim temperature for characterization of the SPF parameters of INCONEL alloy 718SPF.(1) The grain size stability of INCONEL alloy 718SPF during the time for typical SPF of a conventional component should be excellent at $954^{\circ} \mathrm{C}\left(1,750^{\circ} \mathrm{F}\right)$ as exemplified by the grain size data shown in Figure 1.

Table I. Limiting Composition of INCONEL alloy 718SPF (Wt \%)

\begin{tabular}{|c|c|c|c|c|c|c|c|c|c|}
\hline $\mathrm{C}$ & $\mathrm{Mn}$ & $\mathrm{S}$ & $\mathrm{Fe}$ & $\mathrm{Ni}$ & $\mathrm{Cr}$ & $\mathrm{Al}$ & $\mathrm{Ti}$ & $\mathrm{Mo}$ & $\mathrm{Nb}$ \\
\hline \hline 0.05 & \multirow{2}{*}{0.35} & 0.002 & $\mathrm{Bal}$ & 50.0 & 17.0 & 0.20 & 0.65 & 2.80 & 4.75 \\
\hline & & & & 55.0 & 21.0 & 0.80 & 1.15 & 3.30 & 5.25 \\
\hline
\end{tabular}

Table II. Mechanical Properties of Mill Annealed INCONEL alloy 718SPF

\begin{tabular}{|c|c|c|c|c|}
\hline & \multicolumn{4}{|c|}{ Room Temperature Tensile Properties } \\
\hline & \multicolumn{2}{|c|}{$\begin{array}{l}\text { INCONEL alloy } 718 \text { SPF } \\
0.51 \mathrm{~mm}(0.02 \mathrm{in}) \text { gauge }\end{array}$} & \multicolumn{2}{|c|}{$\begin{array}{c}\text { AMS 5596G } \\
\text { Property Requirements }\end{array}$} \\
\hline \multicolumn{5}{|l|}{ Mill Annealed* } \\
\hline $0.2 \%$ Y.S., MPa (ksi) & \multicolumn{2}{|c|}{$852(124)$} & \multicolumn{2}{|c|}{$552(80) \max$} \\
\hline U.T.S., MPa (ksi) & \multicolumn{2}{|c|}{$1,121(163)$} & \multicolumn{2}{|c|}{$965(140) \max$} \\
\hline Elongation, \% & \multicolumn{2}{|c|}{29.0} & \multicolumn{2}{|c|}{30.0} \\
\hline Hardness, Rc & \multicolumn{2}{|c|}{25} & \multicolumn{2}{|c|}{$25 \max$} \\
\hline Grain Size ASTM \# & \multicolumn{2}{|c|}{13} & & \\
\hline \multicolumn{5}{|l|}{ Aged** } \\
\hline $0.2 \%$ Y.S., MPa (ksi) & \multicolumn{2}{|c|}{$1,461(212)$} & \multicolumn{2}{|c|}{$1,034(150) \mathrm{min}$} \\
\hline U.T.S., MPa (ksi) & \multicolumn{2}{|c|}{$1,586(230)$} & \multicolumn{2}{|c|}{$1,241(180) \mathrm{min}$} \\
\hline Elongation, \% & \multicolumn{2}{|c|}{14.0} & \multicolumn{2}{|c|}{$12.0 \mathrm{~min}$} \\
\hline Hardness, Rc & \multicolumn{2}{|c|}{44} & & \\
\hline Aged** & \multicolumn{4}{|c|}{$649^{\circ} \mathrm{C}\left(1200^{\circ} \mathrm{F}\right)$ Tensile Properties } \\
\hline $0.2 \%$ Y.S., MPa (ksi) & \multicolumn{2}{|c|}{$1,116(162)$} & \multicolumn{2}{|c|}{$827(120)$} \\
\hline U.T.S., (MPa (ksi) & \multicolumn{2}{|c|}{$1,201(174)$} & \multicolumn{2}{|c|}{$1,000(145)$} \\
\hline Elongation, \% & \multicolumn{2}{|c|}{22.0} & \multicolumn{2}{|c|}{$5.0 \mathrm{~min}$} \\
\hline Aged $\star \star^{\star}$ & \multicolumn{4}{|c|}{$649^{\circ} \mathrm{C}\left(1200^{\circ} \mathrm{F}\right)$ Stress Rupture Properties } \\
\hline & Life $h$ & Elong. \% & Life $h$ & Elong. \% \\
\hline Stress, $793 \mathrm{MPa}$ (115 ksi) & 12.2 & 9.8 & - & - \\
\hline Stress, 689MPa (100 ksi) & - & - & 23.0 & 4.0 \\
\hline
\end{tabular}

${ }^{\star}$ Continuous Process Anneal: $927^{\circ} \mathrm{C}\left(1700^{\circ} \mathrm{F}\right) / 4.57 \mathrm{M}(15 \mathrm{ft})$ per min. 
**Aging Condition: $954^{\circ} \mathrm{C}\left(1750^{\circ} \mathrm{F}\right) / 1 \mathrm{~h} / \mathrm{AC}$ plus $719^{\circ} \mathrm{C}\left(1325^{\circ} \mathrm{F}\right) / 8 \mathrm{~h} / \mathrm{FC}$ at $56^{\circ} \mathrm{C}\left(100^{\circ} \mathrm{F}\right) / \mathrm{h}$ to $621^{\circ} \mathrm{C}\left(1150^{\circ} \mathrm{F}\right)$ plus $621^{\circ} \mathrm{C}\left(1150^{\circ} \mathrm{F}\right) / 8 \mathrm{~h} / \mathrm{AC}$.

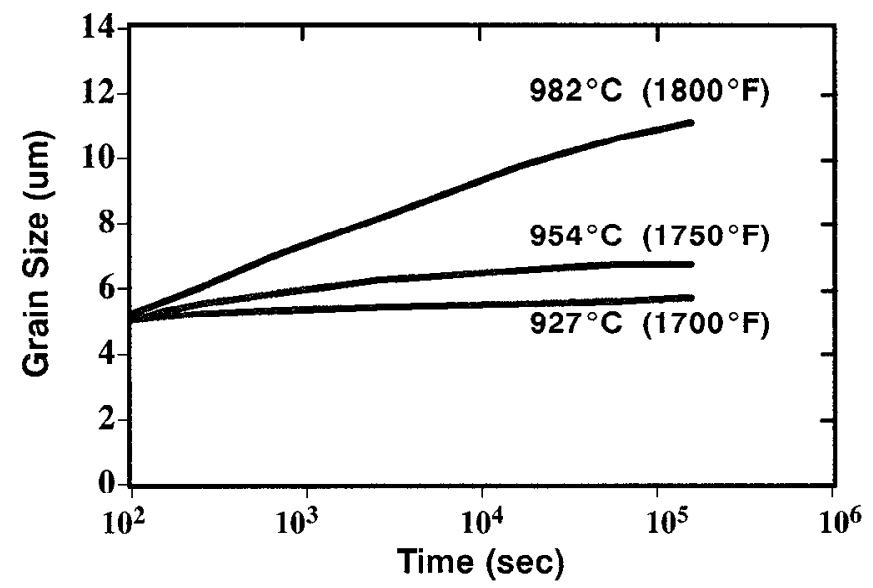

Figure 1. Plot of grain growth versus time at $927^{\circ} \mathrm{C}\left(1700^{\circ} \mathrm{F}\right), 954^{\circ} \mathrm{C}\left(1750^{\circ} \mathrm{F}\right)$ and $982^{\circ} \mathrm{C}\left(1800^{\circ} \mathrm{F}\right)$ for INCONEL alloy $718 \mathrm{SPF}$.

Table III. Axial Fatigue Results For INCONEL Alloy 718SPF vs. Conventional INCONEL Alloy 718

\begin{tabular}{|c|c|c|c|}
\hline Alloy & Test Temperature, F & $\begin{array}{c}\text { Max/Min Stress, } \\
\text { MPa/ksi }\end{array}$ & Cycles \\
\hline 718 & 600 & $100 / 20$ & 242,598 F.G. \\
\hline 718 & 600 & $110 / 22$ & 129,464 F.G. \\
\hline 718 SPF & 600 & $110 / 22$ & $10.033,154$ R.O. \\
\hline 718 SPF & 600 & $140 / 28$ & $>2,625,914$ Tab \\
\hline 718 SPF & 600 & $180 / 36$ & 21,600 \\
\hline 718 & 1000 & $95 / 19$ & $>273,633$ P.H. \\
\hline 718 & 1000 & $95 / 19$ & $>151,516$ F.G. \\
\hline 718 SPF & 1000 & $100 / 20$ & $>11,128,768$ R.O. \\
\hline 718 SPF & 1000 & $120 / 24$ & $>13,999,099$ R.O. \\
\hline
\end{tabular}

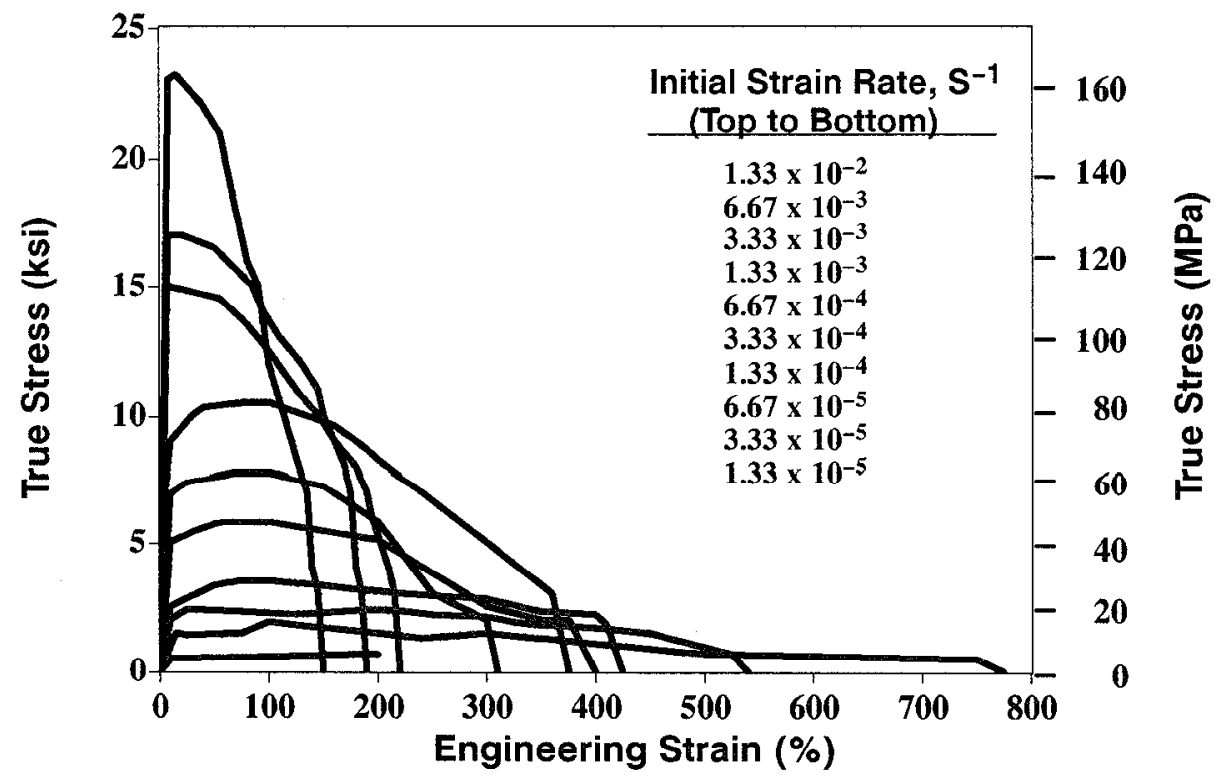

Figure 2. Plot of true stress versus engineering strain for 10 strain rates at $954^{\circ} \mathrm{C}\left(1750^{\circ} \mathrm{F}\right)$ for INCONEL alloy $718 \mathrm{SPF}$. 
To conduct the SPF process parameter evaluation, ten specimens were machined from $1.22 \mathrm{~mm}$ (0.048 in) sheet of INCONEL alloy 718 SPF and tested at $954^{\circ} \mathrm{C}\left(1,750^{\circ} \mathrm{F}\right)$ to failure at varying strain rates from $1.33 \times 10^{-2} \mathrm{~s}^{-1}$ to $1.33 \times 10^{-5} \mathrm{~s}^{-1}$. The test results are presented graphically in Figure 2. A plot of engineering strain (total elongation) versus the initial strain rate is presented in Figure 3. Engineering strain increased from $150 \%$ at an initial strain rate of $1.3 \times 10^{-2} \mathrm{~s}^{-1}$ to $760 \%$ at $3.3 \times 10^{-5} \mathrm{~s}^{-1}$. For the typical SPF strain rates of $10^{-3}$ to $10^{-4} \mathrm{~s}^{-1}$, the available engineering strains are approximately $280 \%$ at the faster strain rate to $480 \%$ at the slower strain rate.

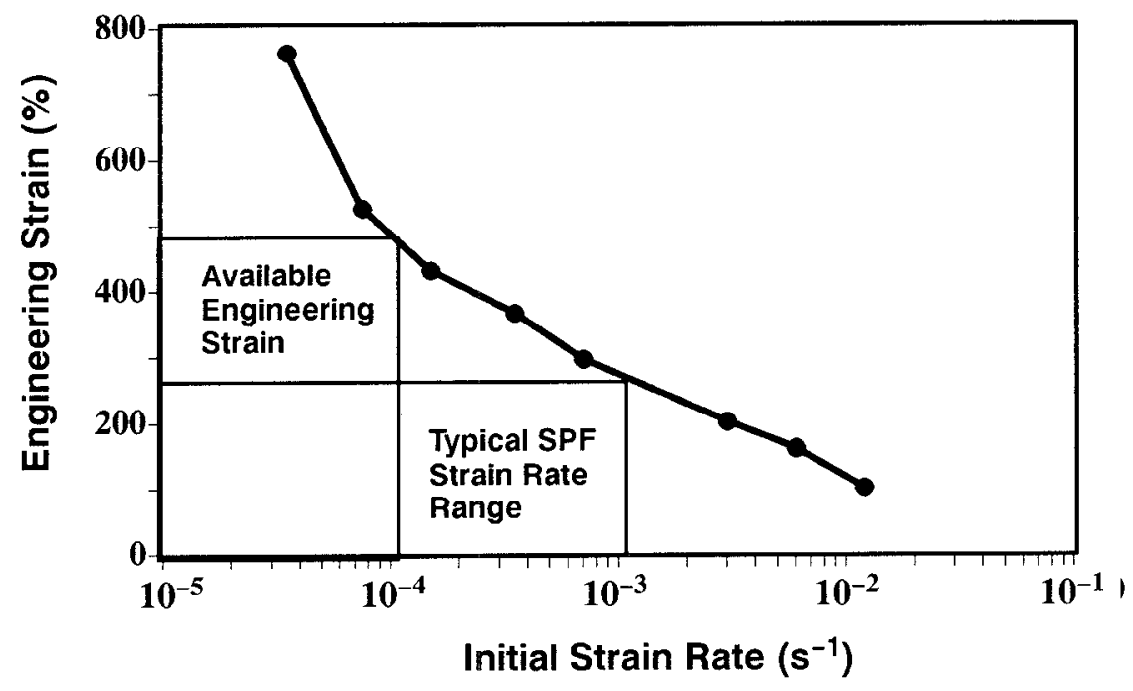

Figure 3. Engineering strain versus strain rate at $954^{\circ} \mathrm{C}\left(1750^{\circ} \mathrm{F}\right)$ for INCONEL alloy 718 SPF. For typical SPF strain rates, the available engineering strain is highlighted.

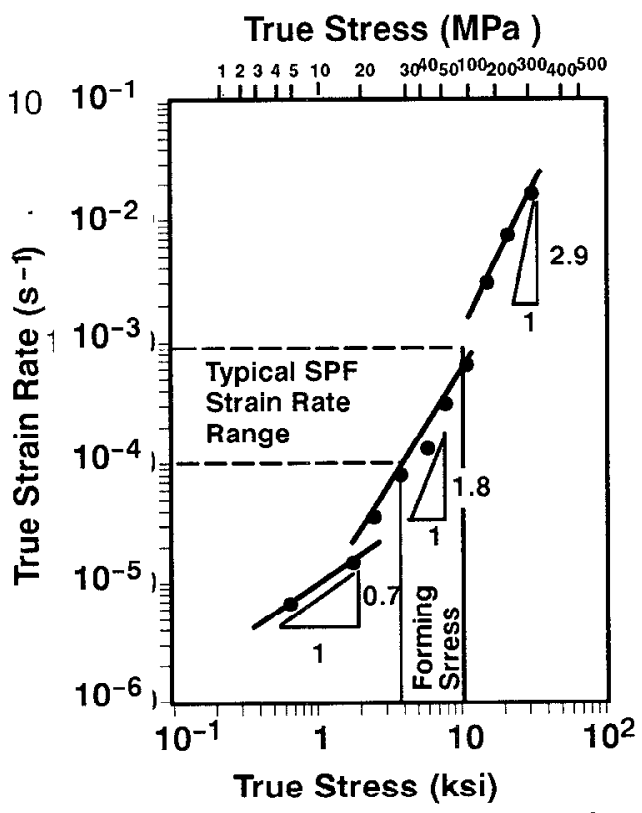

Figure 4. Plot of true rate vs. true stress (both at maximum stress) for INCONEL alloy 718SPF. For typical SPF strain rates, the required forming stress range is highlighted. 
A plot of the true strain rate at maximum stress versus the true stress at maximum stress is presented in Figure 4. This plot defines the maximum stresses that must be generated during SPF in order to deform INCONEL alloy 718SPF at the conventional strain rates of $10^{-3}$ to $10^{-4} \mathrm{~s}^{-1}$. The necessary stress range is from nearly 27.6 to $82.7 \mathrm{MPa}(4$ to $12 \mathrm{ksi})$. Also shown in Figure 4 is the changing value of $\mathrm{n}$ at different strain rates as determined by Equation 1:

$$
\begin{aligned}
& \dot{\epsilon}=k \sigma^{n} \\
& \text { where } \dot{\epsilon}=\text { true strain rate }, \quad \sigma=\text { true stress, } \quad \kappa=\text { constant }
\end{aligned}
$$

The value of $n$ is the slope of $\log \dot{\epsilon}$ vs. $\log \sigma$ and is typically between 1 and 2.5 in the region of most practical SPF interest.(3)

The measure of strain rate sensitivity, $m$, is calculated from the data of Figure 3 and plotted in Figure 5.

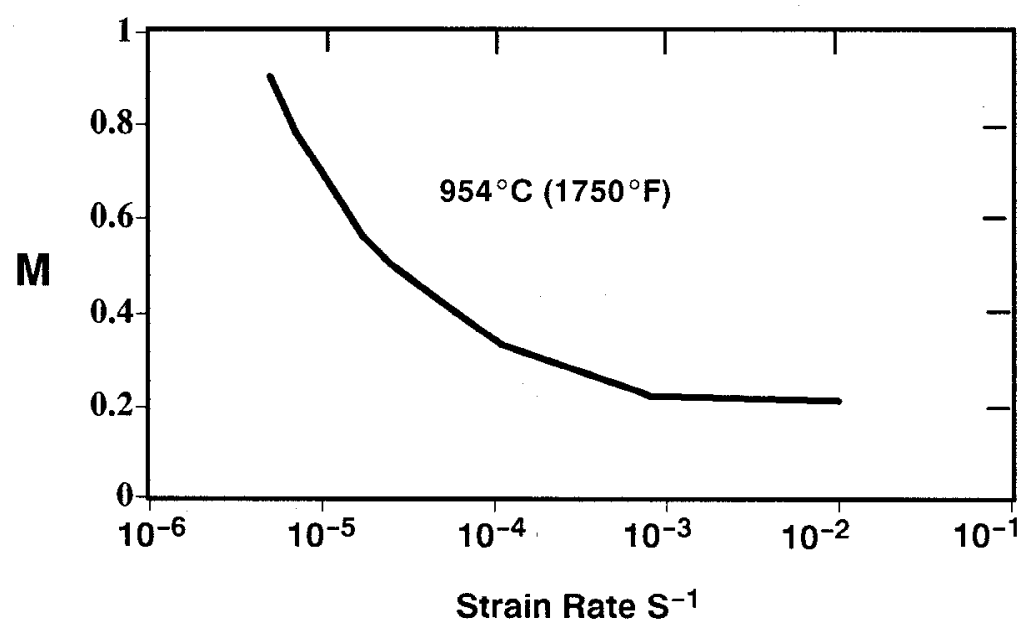

Figure 5. Plot of $m$ values, a measure of strain rate sensitivity versus strain rate at $954^{\circ} \mathrm{C}$ $\left(1750^{\circ} \mathrm{F}\right)$ for INCONEL alloy $718 \mathrm{SPF}$.

Tensile Properties of Superplastically Formed INCONEL alloy 718SPF

The INCONEL alloy 718SPF used in this study was valuated prior to initiating the SPF study for their tensile and stress rupture properties. See Table II. The material meets the room temperature and $649^{\circ} \mathrm{C}\left(1,200^{\circ} \mathrm{F}\right)$ strength and ductility requirements of ASM 5596G as mill annealed and as aged.

Table IV compares the mill annealed properties of INCONEL alloy 718SPF with that of superplastically formed material with reductions in gauge of $13 \%, 19 \%$ and $33 \%$. It is noted that under these conditions the alloy exceeds the annealed property maximum requirements of AMS $5596 \mathrm{G}$ due to the ultrafine grain size of the material. While grain size remains constant, increased deformation during SPF results in reduced hardness, tensile strength and elongation. 
Table IV. Effect of SPF* on Room Temperature Tensile Properties of INCONEL alloy 718 SPF $1.22 \mathrm{~mm}$ (0.048 in.) Gauge Sheet

\begin{tabular}{|l|c|c|c|c|}
\hline \multirow{2}{*}{} & & \multicolumn{3}{|c|}{$\begin{array}{c}\text { Room Temperature Tensile Properties as } \\
\text { Function of Percent Reduction in Gauge }\end{array}$} \\
\cline { 2 - 5 } & Mill Annealed** & $13 \%$ & $19 \%$ & $33 \%$ \\
\hline \hline $0.2 \%$ Y.S ., MPa (ksi) & $815(118)$ & $750(109)$ & $773(112)$ & $700(102)$ \\
\hline U.T.S., MPa (ksi) & $1,114(162)$ & $1,108(161)$ & $1,102(160)$ & $1,003(146)$ \\
\hline Elongation, \% & 33.0 & 22.0 & 22.0 & 14.0 \\
\hline Hardness, Rc & 32 & 29 & 27 & Rb 99 \\
\hline Grain Size ASTM No. & 12 & 12 & 12 & 12 \\
\hline
\end{tabular}

*SPF Conditions: $954^{\circ} \mathrm{C}\left(1750^{\circ} \mathrm{F}\right) / 2.06 \mathrm{MPa}(0.3 \mathrm{ksi})$

${ }^{\star \star}$ Continuous Process Anneal: $927^{\circ} \mathrm{C}\left(1700^{\circ} \mathrm{F}\right) / 4.57 \mathrm{M}(15 \mathrm{ft}) / \mathrm{min}$.

Table $V$ shows the criticality of time $(0,0.33$ and $1.0 \mathrm{~h})$ at $954^{\circ} \mathrm{C}\left(1,700^{\circ} \mathrm{F}\right)$ on restoring aged room temperature tensile ductility (the minimum elongation of AMS $5596 \mathrm{G}$ is $12 \%$ ). Tensile properties and hardness are satisfactory as are tensile properties at $649^{\circ} \mathrm{C}\left(1,200^{\circ} \mathrm{F}\right)$ for the times evaluated. Because of the fine grain size and cavitation effects on the post SPF material, it is not possible to achieve stress rupture properties of ASM $5596 \mathrm{G}$ without incorporating a HIPping step prior to the aging heat treatment as described in Table VI.

Table V. Effect of Time at An Annealing Temperature of $954^{\circ} \mathrm{C}\left(1750^{\circ} \mathrm{F}\right)$ Prior to Aging* after SPF to $33 \%$ Reduction in Gauge

\begin{tabular}{|c|c|c|c|c|}
\hline & \multicolumn{4}{|c|}{ Room Temperature Tensile Properties } \\
\hline & $0.0 \mathrm{~h}$ & $0.33 \mathrm{~h}$ & $1.0 \mathrm{~h}$ & AMS 5596G** \\
\hline $\begin{array}{l}0.2 \% \text { Y.S., MPa } \\
\text { (ksi) }\end{array}$ & $989(143)$ & $1,140(165)$ & $1,193(173)$ & $1,034(150)$ \\
\hline U.T.S., MPa (ksi) & $1,171(170)$ & $1,325(192)$ & $1,372(199)$ & $1,241(180)$ \\
\hline Elongation, \% & 6.0 & 9.0 & 16.0 & 12.0 \\
\hline \multirow[t]{3}{*}{ Hardness, Rc } & 41 & 44 & 44 & 36 \\
\hline & \multicolumn{4}{|c|}{$649^{\circ} \mathrm{C}\left(1200^{\circ} \mathrm{F}\right)$ Tensile Properties } \\
\hline & $0.0 \mathrm{~h}$ & $0.33 \mathrm{~h}$ & $1.0 \mathrm{~h}$ & AMS 5596G** \\
\hline 0.2 Y.S., MPa (ksi) & $855(124)$ & $1,055(153)$ & $1,001(145)$ & $827(120)$ \\
\hline U.T.S., MPa (ksi) & $1,007(146)$ & $1,120(162)$ & $1,155(168)$ & $1,000(145)$ \\
\hline Elongation, \% & 26.0 & 16.0 & 20.0 & 5.0 \\
\hline
\end{tabular}

${ }^{\star}$ Aging Conditions: $719^{\circ} \mathrm{C}\left(1325^{\circ} \mathrm{F}\right) / 8 \mathrm{~h} / \mathrm{FC}$ at $56^{\circ} \mathrm{C}\left(100^{\circ} \mathrm{F}\right) / \mathrm{h}$ to $621^{\circ} \mathrm{C}\left(1,150^{\circ} \mathrm{F}\right)+621^{\circ} \mathrm{C}\left(1,150^{\circ} \mathrm{F}\right) / 8 \mathrm{~h} / \mathrm{AC}$ **Minimum Properties

Table VI. Effect of HIPping on Stress Rupture Ductility

\begin{tabular}{|c|c|c|}
\hline \multirow{3}{*}{ Sample Conditions } & \multicolumn{2}{|c|}{ Stress Rupture Conditions } \\
\hline & \multicolumn{2}{|c|}{$649^{\circ} \mathrm{C}\left(1200^{\circ} \mathrm{F}\right) / 690 \mathrm{MPa}(100 \mathrm{ksi})$} \\
\hline & Life $(h)$ & Elongation (\%) \\
\hline SPF + Anneal* & Failed on Loading & 50.3 \\
\hline $\mathrm{SPF}+\mathrm{Age}^{\star \star}$ & 47.1 & 2.1 \\
\hline $\mathrm{SPF}+\mathrm{HIP}+\mathrm{Age}^{\star \star \star}$ & 43.1 & 23.0 \\
\hline
\end{tabular}

* Sample as superplastically reduced $32 \%$ in gauge then annealed at $1038^{\circ} \mathrm{C}\left(1900^{\circ} \mathrm{F}\right) / 1 \mathrm{~h} / \mathrm{AC}$

* * Sample was superplastically reduced $17 \%$ in gauge then annealed $1038^{\circ} \mathrm{C}\left(1900^{\circ} \mathrm{F}\right) / 1 \mathrm{~h} / \mathrm{AC}$ followed by aging at $719^{\circ} \mathrm{C}\left(1325^{\circ} \mathrm{F}\right) / 8 \mathrm{~h} / \mathrm{FC}$ at $56^{\circ} \mathrm{C}\left(100^{\circ} \mathrm{F}\right) / \mathrm{h}$ to $621^{\circ} \mathrm{C}\left(1150^{\circ} \mathrm{F}\right) / 8 \mathrm{~h} / \mathrm{AC}$

$\star \star *$ Sample was superplastically reduced $46 \%$ in gauge, HIPed at $954^{\circ} \mathrm{C}\left(1750^{\circ} \mathrm{F}\right) / 30 \mathrm{~min}$. and $400 \mathrm{MPa}$ (58 ksi), then aged per above conditions

AMS 5596G Specification: minimum $23 \mathrm{~h}$ life at $649^{\circ} \mathrm{C}\left(1200^{\circ} \mathrm{F}\right) / 690 \mathrm{MPa}(100 \mathrm{ksi})$ and $4 \%$ elongation 


\section{Cavitation}

The propensity of INCONEL alloy 718 SPF to form pores during superplastically forming (cavitation) was measured (using an image analysis software package) by metallographic examination of the tensile specimens tested to fracture at varying initial strain rates at $954^{\circ} \mathrm{C}$ $\left(1,750^{\circ} \mathrm{F}\right)$ as exemplified in Table VII. This alloy is subject to cavitation during SPF with the degree of cavitation increasing with decreasing initial strain rate. At an initial strain rate of $10^{-2} \mathrm{~s}^{-1}$, the area of cavitation, as measured near the fracture tip, is less than $0.01 \%$ for a tensile elongation of $150 \%$. However, the degree of cavitation increases at a strain rate of $10^{-3} \mathrm{~s}^{-1}$ to $2.0 \%(369 \%$ elongation); becoming $10.3 \%$ at a strain rate of $10^{-5} \mathrm{~s}^{-1}$ (538\% elongation). Table 6 shows that as the strain rate is decreased, the average cavity size and roundness coefficient increases. The average roundness coefficient is an indication of the degree of diffusion associated with cavity growth. A roundness coefficient of one indicates a perfect circular shape while a smaller value of the roundness coefficient relates more to cavity elongation. The increase in roundness coefficient at the strain rate of $10^{-3} \mathrm{~s}^{-1}$ or less suggests that cavity growth by diffusion is becoming increasingly significant for decreasing strain rates (longer times at temperature).

Table VII. The Effect of Strain Rate at $954^{\circ} \mathrm{C}\left(1750^{\circ} \mathrm{F}\right)$ on The Size and Area of Cavitation of INCONEL alloy 718SPF The Average Roundness Coefficient of The Cavities Is Also Presented

\begin{tabular}{|c|c|c|c|}
\hline Strain Rate, $\mathrm{s}^{-1}$ & $1.3 \times 10^{-2}$ & $1.3 \times 10^{-3}$ & $6.7 \times 10^{-5}$ \\
\hline Total Elongation $1, \%$ & 150.0 & 369.0 & 538.0 \\
\hline Cavitation Area $2, \%$ & $<0.01$ & 2.60 & 10.60 \\
\hline Avg. Cavity Area, um² & 5.20 & 145.0 & 580.0 \\
\hline Avg. Roundness Coefficient ${ }^{3}$ & 0.47 & 0.63 & 0.63 \\
\hline
\end{tabular}

${ }^{1}$ Specimen tested to fracture

${ }^{2}$ Based on a measured area of $0.83 \mathrm{~mm}^{2}$ near the fracture tip

${ }^{3}$ Defined as $(4 \pi \text { area)/perimeter })^{2}$ where a value of 1.0 represents a perfect circle and values less than 1.0 represent deviation from a circle

Because SPF components are normally produced at strain rates of $10^{-3} \mathrm{~s}^{-1}$ to $10^{-4} \mathrm{~s}^{-1}$ with actual total elongations of less than $200 \%$, four INCONEL alloy.718SPF specimens were evaluated at $954^{\circ} \mathrm{C}\left(1,750^{\circ} \mathrm{F}\right)$ for strains of $86 \%$ and $194 \%$ at an initial strain rate of $10^{-3} \mathrm{~s}^{-1}$ and for strains of $73 \%$ and $132 \%$ at an initial strain rate of $10^{4} \mathrm{~s}^{1}$. The area of cavitation was measured metallographically using an area of $0.83 \mathrm{~mm}^{2}\left(0.0012 \mathrm{in}^{2}\right)$ from the gauge length. The results are presented in Table VIII. The data show that increasing elongation and decreasing strain rate, increase the area of cavitation. However, at total elongations of less than $200 \%$ at either a strain rate of $10^{-3}$ or $10^{-4} \mathrm{~s}^{-1}$, the area of cavitation is less than $0.5 \%$ and can be held below $0.1 \%$ for elongations of less than $100 \%$ at a strain rate of $10^{-3} \mathrm{~s}^{-1}$. Typical cavity size, as shown in Table VIII, is again larger for the slower strain rate and greater total elongation. Cavitation tends to nucleate and grow around inclusions present in the alloy. Analysis of the number of cavities of a given size as a function of total strain shows a significant increase in the 
number of cavities within the smallest size range examined (0 to $\left.2 \mu \mathrm{m}^{2}\right)$ as the elongation increases, supporting the concept that cavities are continuously being nucleated throughout the test. Thus, the extent and distribution of inclusions becomes an important issue in superplastic forming of INCONEL alloy 718SPF.

Table VIII. The Effect of Strain Rate and Total Strain at $954^{\circ} \mathrm{C}\left(1750^{\circ} \mathrm{F}\right)$ on the Size and Area of Cavitation of INCONEL alloy 718SPF.

\begin{tabular}{|l|c|c|c|c|}
\hline Initial Strain Rate, $\mathrm{s}^{-1}$ & $1.3 \times 10^{-3}$ & $1.3 \times 10^{-4}$ & $1.3 \times 10^{-3}$ & $1.3 \times 10^{-4}$ \\
\hline Total Strain, \% & 86.0 & 73.0 & 194.0 & 132.0 \\
\hline Cavitation Area, \% & 0.04 & 0.18 & 0.45 & 0.34 \\
\hline Avg. Cavity Size, um ${ }^{2}$ & 2.40 & 8.90 & 10.50 & 11.20 \\
\hline
\end{tabular}

\section{Summary}

The aim of this paper is to show the applicability of INCONEL alloy 718SPF to current superplastic forming practice and equipment; to describe the processing parameters and to define the properties and microstructure of superplastically formed material. Based on this effort, a number of conclusions can be drawn:

1. INCONEL alloy 718SPF can be produced with an ASTM grain size of \#10 or smaller and, subsequently, superplastically formed at $954^{\circ} \mathrm{C}\left(1750^{\circ} \mathrm{F}\right)$ using argon gas pressures of 2.1 MPa (300 psi).

2. For INCONEL alloy $718 \mathrm{SPF}$, the elongation to failure increases markedly with decreasing strain rate, exceeding $350 \%$ at an initial strain rate of $1.3 \times 10^{-3} \mathrm{~s}^{-1}, 450 \%$ at $1.3 \times 10^{-4} \mathrm{~s}^{-1}$ and $750 \%$ at $3.3 \times 10^{-5} \mathrm{~s}^{-1}$.

3. For INCONEL alloy $718 \mathrm{SPF}$, the maximum true stress decreases with decreasing strain rate becoming less than $71.7 \mathrm{MPa}(10.4 \mathrm{ksi})$ at an initial strain rate of $1.3 \times 10^{-3} \mathrm{~s}^{-1}$ and less than $27.6 \mathrm{MPa}(4 \mathrm{ksi})$ at $1.3 \times 10^{-4} \mathrm{~s}^{-1}$.

4. INCONEL alloy 718 SPF retains its original tensile properties after superplastic forming, at least, through engineering strains approximating $200 \%$.

5. AMS aged tensile properties are achieved through standard aging heat treatments

6. The development of cavities at tensile failure is insignificant at a strain rate of $10^{-2} \mathrm{~s}^{-1}$ (less than $0.01 \%$ by area) but becomes increasingly important as the strain rate decreases.

\section{References}

1. M. W. Mahoney, "Superplastic Properties of INCONEL alloy 718," in Proceedings of the International Symposium on the Metallurgy and Applications of INCONEL alloy 718, June, 1989, Pittsburgh, PA, published by ASM. 
2. Y. Ma and T. G. Langdon, Private Communication, "Obscrvations of Cavitation in Deformed INCONEL alloy 718", University of Southern California, February 1992.

3. R. C. Gifkins, "Mechanisms of Superplasticity." in Proceedings of Symposium on Super plastic Forming of Structural Alloys, June 1982, San Diego, CA, published by AIME. 